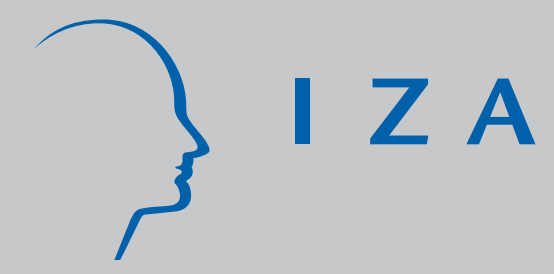

IZA DP No. 1753

How Important Is Homeland Education for

Refugees' Economic Position in The Netherlands?

J oop Hartog

Aslan Zorlu

September 2005 


\title{
How Important Is Homeland Education for Refugees' Economic Position in The Netherlands?
}

\author{
Joop Hartog \\ AIAS, University of Amsterdam \\ and IZA Bonn \\ Aslan Zorlu \\ AIAS, University of Amsterdam
}
Discussion Paper No. 1753
September 2005

\author{
IZA \\ P.O. Box 7240 \\ 53072 Bonn \\ Germany \\ Phone: +49-228-3894-0 \\ Fax: +49-228-3894-180 \\ Email: iza@iza.org
}

\begin{abstract}
Any opinions expressed here are those of the author(s) and not those of the institute. Research disseminated by IZA may include views on policy, but the institute itself takes no institutional policy positions.
\end{abstract}

The Institute for the Study of Labor (IZA) in Bonn is a local and virtual international research center and a place of communication between science, politics and business. IZA is an independent nonprofit company supported by Deutsche Post World Net. The center is associated with the University of Bonn and offers a stimulating research environment through its research networks, research support, and visitors and doctoral programs. IZA engages in (i) original and internationally competitive research in all fields of labor economics, (ii) development of policy concepts, and (iii) dissemination of research results and concepts to the interested public.

IZA Discussion Papers often represent preliminary work and are circulated to encourage discussion. Citation of such a paper should account for its provisional character. A revised version may be available directly from the author. 
IZA Discussion Paper No. 1753

September 2005

\section{ABSTRACT}

\section{How Important Is Homeland Education for Refugees' Economic Position in The Netherlands?*}

We use data on refugees admitted to the Netherlands that include registration of education in their homeland by immigration officers. Such data are seldom available. We investigate the quality and reliability of the registrations and then use them to assess effects on refugees' economic position during the first five years after arrival. The most remarkable finding is the absence of returns to higher education.

JEL Classification: $\quad$ I21, J31, J61

Keywords: immigrants, refugees, education, earnings, employment

Corresponding author:

Joop Hartog

Department of Economics

University of Amsterdam

Roetersstraat 11

1018 WB Amsterdam

The Netherlands

Email: J.Hartog@uva.nl

\footnotetext{
* We gratefully acknowledge comments from Mars Cramer, Vluchtelingenwerk Nederland and from participants in the WODC seminar (Ministry of Home Affairs) and in the LoWER Annual Conference, Mannheim, April 16 2005, where this paper served as the basis for a Keynote presentation. The paper is part of a joint project with the Dutch Statistical Office CBS; we are grateful to Arno Sprangers and Han Nicolaas for essential input in the creation of the database. We are particularly grateful to Harry van den Tillaart from ITS for providing us with their classification of individuals' education.
} 


\section{Introduction}

Education is commonly held to be a key variable for economic success of immigrants in their destination country. Several studies have indicated that it matters very much whether this education has been acquired in the origin country prior to migration, or in the destination country. Friedberg (2000) even shows that properly accounting for education obtained before migration can explain the initial earnings disadvantage of immigrants. Existing studies that make the distinction never have direct observations on the decomposition: it is always inferred, usually from highest level of education attained and age at immigration (Friedberg, 2000; Nekby, 2002; Cortes, 2004). An exception is Kee (1993) who uses direct observations for immigrants to the Netherlands. In this paper we use registration by immigration officers obtained when immigrants apply for admission to The Netherlands. We investigate the quality of the data and then use the observations to assess the importance for economic success during the first five to six years after admission. Our key finding is that education beyond secondary does not yield any additional monetary returns. After thoroughly testing for the reliability of this conclusion, we are convinced that this is a real effect.

In the next section we introduce our data. In section 3 we discuss reliability of registered education. Section 4 presents analyses of the effect of education on the probability of employment and the probability of receiving a social benefit. Section 5 presents the analyses of the schooling effect on wages. Section 6 considers the relation between initial disadvantage and later annual growth rate. Section 7 concludes.

\section{Data selection}

We use the Immigrant Panel, described in Appendix A. The Immigrant Panel has been created by linking registration of entering immigrants by the Dutch immigration service IND with observations on socio-economic variables by the national statistical bureau in the RIO files, where the linking has taken place through the registration of population GBA. For a large share of asylum applicants from 1995 to 2000, information on homeland education has been coded by ITS researchers in a standard classification scheme.

We will analyse data for applicants who are still present in the Netherlands in 2000. Following an entry cohort and hence, using information on returns as well, is not an attractive alternative, as it would only be feasible for cohorts entering in 1998 or later (when the electronic IND registration started): it would restrict the analysis to fairly recently arrived immigrants only. We might also have opted for using all observations in the database up to their last moment of observation; final observations for individuals would then refer to 2000 or to year of departure if earlier. Our choice implies that we do not observe individuals that have left before 2000. This would be disturbing if it generates selectivity on variables or processes we are interested in. We

are fairly confident that this is not the case, however. Our sample is restricted to those who have a valid permit to stay. We can observe departures for arrivals in 1998 or later. Among those with a permanent residential status in that sample, we only observe 5 people who have left (out of perhaps some 10000 admissions). Those with a temporary permission to stay may be expelled when their homeland is declared safe 
(eg former Yugoslavia). In that case, return migration is an exogenous event and need not worry us.

The basic IND file contains 218446 individuals requesting asylum between 1995 and 2000. 91580 of these individuals were found in the population register GBA, either admitted or still in the application procedure; the others had reached the end of the application procedure and were not admitted. 16339 were successfully matched with the RIO files (a 1:3 sample); of these individuals we have 35340 observations. In 2000, 13436 matched individuals were still present; of these we have 31323 observations on the period 1995-2000. By year of arrival, the sample spans the decade of the 1990's, but most observations date from 1996 or later: $3.6 \%$ arrived in 19901995, the remainder in 1996-2000. There is also some attrition from using the household as sampling unit. The initial recording covers all members of a household; if someone later leaves the household this means leaving the sample.

To create a reasonably homogenous sample, we require individuals to have a valid permit to stay. This is to exclude individuals whose application is still being processed, and who may later be denied access ${ }^{1}$. The records contain many statements on the applicant's formal status, but there is no track record of progress in the decision making process. Dates of decisions are not registered. So, we decided to stay on the safe side and distinguish only three categories: A status (permanent permission to stay; includes also immigrants granted Dutch citizenship in 2001), AMA (entered as independent minor, i.e. not older than 18), and preliminary status (all other). Presumably, AMA refers to status upon entry, A status and preliminary status refer to the situation in 2000 (as last recorded status); status updates (by IND) occur, but the date of last recording is not known. Table 1 gives the distribution by status and country of origin.

\section{Table 1. Admissions by title of residence and country of origin}

\begin{tabular}{lrrrr} 
& A-status & \multicolumn{2}{c}{ AMA Preliminary } & Total $(\mathrm{N}=100)$ \\
\cline { 1 - 4 } & $\%$ & & & \\
Iran & 42.14 & 0.74 & 57.12 & 674 \\
Iraq & 35.51 & 0.32 & 64.17 & 3,123 \\
Somalia & 15.90 & 15.33 & 68.76 & 874 \\
China & 1.17 & 53.38 & 45.45 & 429 \\
Afghanistan & 37.19 & 1.05 & 61.76 & 2,947 \\
Sudan & 28.45 & 4.38 & 67.17 & 594 \\
Former Yugoslavia & 27.52 & 0.16 & 72.33 & 1,272 \\
Soviet Union & 28.08 & 2.91 & 69.01 & 755 \\
Other countries & 16.11 & 13.51 & 70.38 & 2,768 \\
& & & & \\
Total & 28.36 & 6.20 & 65.44 & 13,436 \\
\hline
\end{tabular}

In our sample of refugees, Iraq, Afghanistan and Other countries each contribute about one fifth, $11 \%$ are from former Yugoslavia; Iran, Somalia, Sudan and the Soviet

\footnotetext{
${ }^{1}$ The sample also contains individuals who are in the application process and who are registered at GBA. This number is unknown but very small. (The usual procedure is GBA registration after obtaining residential status.)
} 
Union each contribute some 5-6 and 3\% are from China. About two thirds of the refugees have a preliminary status, just over a quarter has A status, 6\% are AMA. AMA's are mostly from China and Somalia. Among refugees with A status Iran, Iraq and Afghanistan are over-represented.

\section{Measuring education}

We are specifically interested in the relevance of homeland education for socioeconomic position after immigration, but we have reason to be suspicious about the reliability of recorded education. The original documents may register the applicant's education, but if so, registration is not according to a standardized classification system. ITS analysts have coded the entries to a standard classification. From analysis by ITS, we know that education is missing in many cases and that there is reason for doubting the reliability of the recorded levels. We also know that education is not an important variable in the decision process and that immigration officers have no special interest. In fact, they consider it irrelevant and often ignore it. Hence, prior to attempting any analysis we should assess the quality of measurement.

Table 2 Education level by country of origin, percentages

\begin{tabular}{lrrrrrrrrrrr}
\hline & None & $\begin{array}{r}1-3 \\
\text { basic }\end{array}$ & $\begin{array}{r}4-5 \\
\text { basic }\end{array}$ & Basic & $\begin{array}{r}\text { Ext. } \\
\text { basic }\end{array}$ & $\begin{array}{r}\text { Sec. } \\
\text { gen. }\end{array}$ & $\begin{array}{r}\text { Sec. } \\
\text { voc }\end{array}$ & $\begin{array}{r}\text { Some } \\
\text { tert. }\end{array}$ & $\begin{array}{r}\text { Tert Missi } \\
\text { ng }\end{array}$ \\
\hline Iran & 2.82 & 0.89 & 1.34 & 2.23 & 10.09 & 23.74 & 2.23 & 3.12 & 10.98 & 42.58 & 674 \\
Iraq & 4.67 & 1.44 & 2.34 & 4.13 & 9.54 & 8.36 & 3.30 & 3.39 & 12.33 & 50.50 & 3,123 \\
Somalia & 20.82 & 8.92 & 5.38 & 7.32 & 11.90 & 10.64 & 0.80 & 0.57 & 2.52 & 31.12 & 874 \\
China & 4.20 & 15.38 & 20.05 & 14.22 & 13.99 & 4.66 & 0.93 & 0.00 & 0.23 & 26.34 & 429 \\
Afghanistan & 5.09 & 1.26 & 2.21 & 4.21 & 4.48 & 9.54 & 0.71 & 3.02 & 9.74 & 59.76 & 2,947 \\
Sudan & 5.72 & 1.52 & 2.86 & 5.05 & 8.92 & 11.11 & 2.02 & 5.56 & 18.52 & 38.72 & 594 \\
F. Yugoslavia & 6.53 & 0.94 & 2.99 & 4.64 & 19.03 & 12.03 & 10.46 & 2.04 & 2.67 & 38.68 & 1,272 \\
F. SovietUnion & 4.90 & 2.25 & 1.85 & 4.77 & 16.16 & 16.16 & 5.56 & 1.85 & 13.51 & 32.98 & 755 \\
Other countries & 9.68 & 4.34 & 6.11 & 10.91 & 12.17 & 11.92 & 1.88 & 2.13 & 4.34 & 36.52 & 2,768 \\
& & & & & & & & & & & \\
Total (\%) & 6.97 & 2.90 & 3.86 & 6.10 & 10.54 & 11.06 & 2.90 & 2.63 & 8.45 & 44.60 & \\
Total (N) & 937 & 390 & 518 & 820 & 1,416 & 1,486 & 389 & 353 & 1,135 & 5,992 & 13,436 \\
\hline
\end{tabular}

Table 2 presents the distribution by education levels, distinguished by country of origin. The first thing to note is that in $45 \%$ of the cases education is missing. $7 \%$ has no education at all, $23 \%$ has basic (including extended basic), $14 \%$ has secondary and $11 \%$ has tertiary education. If among missing recordings individuals have the same distribution by education as those who are observed (which may well be true, see below), $13 \%$ of all refugees would have no education at all and more than half (55\%) would have no more than extended basic education. $15 \%$ would have a higher education. This points to a rather unequal distribution of education.

Refugees from China, of whom many are AMA, have remarkably low levels of education and so have refugees from (former) Yugoslavia. Among refugees from Iran there is a remarkably high share with secondary education, Sudan has relatively many highly educated refugees, the distribution from the Soviet Union is rather bimodal: 
high shares with extended lower and with high education. Refugees from Iraq tend to be at the high end of the distribution, refugees from Somalia tend towards the low end. Table C1 in the Appendix gives a more compact overview, with education aggregated into three levels only. In the total sample, 20\% has primary education, $27 \%$ secondary, $8 \%$ tertiary and for $45 \%$ education is missing. By title of residence (not shown here), refugees with A status have higher average education level, AMA's have lower average level of education. Among all refugees, $28 \%$ has A status, while among refugees with tertiary education, $43 \%$ has A status.

We also have observations on education recorded by CWI, the public employment service that assists individuals in finding a job. Registration as job seeker is a requirement for obtaining social benefit. Clearly, this registration is highly selective. But we might assume that employment service agents are more dedicated in registering education, as it is an important instrument for the service they have to provide: they have an interest in accurate assessment. However, they might also apply censoring and only register education they consider relevant for the Dutch labour market. We do not know whether individuals have obtained any additional education in The Netherlands. Upon a first visit to the employment agency this seems unlikely, but with later visits an update might have taken place.

Table 3. Education ITS and education CWI

\begin{tabular}{|c|c|c|c|c|c|c|c|c|}
\hline \multicolumn{9}{|c|}{ Education CWI } \\
\hline & Unkn. & Basic & $\begin{array}{l}\text { Lower } \\
(v+g)\end{array}$ & $\begin{array}{r}\text { Interm } \\
(v+g)\end{array}$ & $\begin{array}{l}\text { Higher } \\
\text { vocat. }\end{array}$ & $\begin{array}{r}\text { Universit } \\
y\end{array}$ & Missing & Total \\
\hline \multicolumn{9}{|l|}{ Education ITS } \\
\hline No education & 9.09 & 9.99 & 5.69 & 1.33 & 1.00 & 0.66 & 8.68 & 6.97 \\
\hline 1-3year Primary & 3.74 & 4.17 & 2.97 & 0.96 & 0.14 & 0.26 & 3.41 & 2.90 \\
\hline 4-5year Primary & 5.88 & 5.78 & 4.17 & 1.33 & 0.14 & 0.40 & 4.35 & 3.86 \\
\hline Primary & 4.81 & 8.47 & 7.08 & 3.91 & 0.29 & 0.26 & 6.80 & 6.10 \\
\hline Extended primary & 13.9 & 11.68 & 14.74 & 9.14 & 1.85 & 1.32 & 11.3 & 10.54 \\
\hline Secondary, general & 6.95 & 9.49 & 13.35 & 20.58 & 9.56 & 4.50 & 10.13 & 11.06 \\
\hline Secondary, vocat. & 0.53 & 2.57 & 3.67 & 5.68 & 3.71 & 1.06 & 2.44 & 2.90 \\
\hline Some Tertiary & 2.67 & 1.48 & 1.64 & 5.01 & 5.71 & 5.17 & 2.16 & 2.63 \\
\hline Tertiary & 8.56 & 3.20 & 3.23 & 8.85 & 28.96 & 40.26 & 5.63 & 8.45 \\
\hline Missing & 43.85 & 43.17 & 43.45 & 43.22 & 48.64 & 46.09 & 45.10 & 44.6 \\
\hline Total $(\mathrm{N}=100)$ & 187 & 2,372 & 1,581 & 1,356 & 701 & 755 & 6,484 & 13,436 \\
\hline
\end{tabular}

From Table 3 we may note first of all that the missing observations do not match: they are not concentrated as single diagonal entry in the cell (missing ITS, missing CWI). Missing observations must result from different processes in the two agencies and are not a unique property of the respondent. The overall proportions are about equal, at $45 \%$ for ITS and $49 \%$ for CWI but this must be coincidence, as ITS missings are due to non-registration by the immigration officer while CWI missings must be due to absence of contact with the employment service. Interestingly, the proportion of missing observations on ITS education is virtually the same for every level of CWI education. If we are justified in assuming that CWI registration is reasonably reliable, this would imply that missing observations in ITS are unrelated to level of education, and hence, that the distribution of observed education is representative for all 
refugees: we can relate the frequencies to only those individuals for whom education has been registered.

If we group the levels of education in primary, secondary, tertiary (to allow for matching classifications), we can calculate that in $6.6 \%$ of the cases, the ITS level is higher than the CWI level, while in $5 \%$ the reverse holds. This points to some upward bias in the ITS registration relative to the CWI registration, as one might have anticipated: ITS is the individual's assessment without any check, CWI coding is based on the registration by an employment agency that has interest in accurate assessment. The employment agents translate foreign education into the guessed Dutch equivalent and might perhaps be inclined to some downward bias because of unfamiliarity with foreign schooling systems. But the bias is quite modest, which lends credibility to the ITS data.

There is certainly no agreement between IND and CWI on individuals' level of education. Table 4 with education registered in three levels, shows this quite clearly. If we consider only cases for which both institutions record an education level (ie, exclude missing observations), the diagonal elements in Table 5 would be $0.50,0.65$ and 0.65 , meaning that for given classification by CWI in no more that two thirds of the cases would ITS record the same level.

Table 4. Education ITS and education CWI, three levels

\begin{tabular}{l|rrrrr}
\hline \multirow{2}{*}{ ITS } & \multicolumn{5}{|c}{ CWI } \\
\cline { 2 - 6 } & Primary Secondary & Tertiary & Missing & Total \\
\hline Primary & 28.06 & 14.20 & 1.58 & 23.24 & 19.83 \\
Secondary & 25.13 & 36.64 & 16.28 & 26.03 & 27.12 \\
Tertiary & 3.60 & 5.82 & 34.82 & 5.63 & 8.45 \\
Missing & 43.22 & 43.34 & 47.32 & 45.10 & 44.60 \\
& & & & & \\
Total & 100 & 100 & 100 & 100 & 100 \\
\hline
\end{tabular}

We have analysed possible patterns of non-recording of education by IND officers by running a logistic regression (see Appendix Table C2). Registration of education is indeed related to some variables: education is more often registered for immigrants who are older at arrival and for men, it is better known for later arrivals, and there are significant differences between countries of origin: better known for China, Soviet Union and Somalia, less often known for Afghanistan and Yugoslavia. "Undocyears" and "Statuswait" also have significant, negative, effect on the probability of registration. Undocyears is IND registration year minus GBA registration year (if positive), which refers to years spent without residential permit, while Statuswait is measured as GBA registration year minus IND registration year (if positive), which measures time spent in refugee homes waiting for a decision on the application.

We have made inquiries with IND and with immigration officers who do the intake interviews and registration of immigrants. They could not give any explanation on the pattern of registration of education and they are absolutely unaware of any systematic effects.

We conclude that non-recording of level of education by IND (and hence, ITS) has different incidence by country of origin, years of arrival and gender of the refugees, 
but there is no indication of a systematic rule applied by immigration officers. We do not see any reason to fear that non-registration of education is related to level of education. Neither do we see any indication that non-registration or erroneous registration would be related to unobserved ability of applicants. From comparing ITS and CWI registration, we conclude that there is no indication of systematic upward or downward bias in the level of education recorded by ITS. But the substantial variation in the cross-classification of the two registrations indicates that measurement error in the level of education is far from negligible.

We have considered using information on homeland occupation (also coded by ITS) as a variable to assess the reliability of registered education. But a cross-tabulation of education and occupation shows wide dispersion of education by occupation. Moreover, many educations are so low, and so little specific that it would be hard to use the additional information to test the reliability of education. There are auto mechanics and farm hands with tertiary education and pharmacists with just extended basic education. The matrix is simply too far removed from diagonality to yield useful additional information. Interestingly, our second logistic regression in Appendix Table C2 shows no relation between recording education and recording occupation.

To get a feel for the possible magnitude of measurement errors in our education data we use the following approach. We have two measures of an individuals' education, $\mathrm{S}_{\mathrm{iT}}$ as measured by ITS and $\mathrm{S}_{\mathrm{iC}}$ as measured by CWI, both measured in years (we have translated education levels to years). Assume:

$$
\begin{aligned}
& S_{i T}=S_{i}+e_{i T} \\
& S_{i C}=S_{i}+e_{i C}
\end{aligned}
$$

Both measurements report individuals i's true education, but with different measurement errors. Assuming that the errors are independent of the true value, we can write for the variances:

$$
\begin{aligned}
& \mathrm{V}_{\mathrm{T}}=\mathrm{V}+\mathrm{V}_{\mathrm{eT}} \\
& \mathrm{V}_{\mathrm{C}}=\mathrm{V}+\mathrm{V}_{\mathrm{eC}}
\end{aligned}
$$

where $\mathrm{V}$ measures the variance of true education across individuals, and $\mathrm{V}_{\mathrm{e}}$. measures the variances in the error terms.

We can write the covariance $\mathrm{V}_{\mathrm{CT}}$ as

$$
\begin{aligned}
\mathrm{V}_{\mathrm{CT}} & =\mathrm{E}\left\{\left(\mathrm{S}_{\mathrm{iT}}-\mathrm{E}\left(\mathrm{S}_{\mathrm{iT}}\right)\right)\left(\mathrm{S}_{\mathrm{iC}}-\mathrm{E}\left(\mathrm{S}_{\mathrm{iC}}\right)\right)\right\} \\
& =\mathrm{E}\left\{\left(\mathrm{S}_{\mathrm{iT}}-\mathrm{E}\left(\mathrm{S}_{\mathrm{i}}\right)\right)\left(\mathrm{S}_{\mathrm{iC}}-\mathrm{E}\left(\mathrm{S}_{\mathrm{i}}\right)\right)\right\},
\end{aligned}
$$

under the assumption of zero expected measurement error and independence of true education levels. Substituting the definitions (1) and (2), we can write this as

$$
\mathrm{V}_{\mathrm{CT}}=\mathrm{V}+\rho \sqrt{ } \mathrm{V}_{\mathrm{eT}} \mathrm{V}_{\mathrm{eC}}
$$


From the three equations (3), (4) and (6) we can identify the three variances if we know (or make assumptions on) the correlation between the two measurement errors. The variance in ITS education is 16.50, the variance in CWI education is 13.67 and the covariance is 8.38 . Solving ${ }^{2}$ the equations for selected values of the correlation coefficient gives the results plotted in Figure 1. According to these results, anything is possible, even if we discard the area with negative true variance. The only firm conclusion is that measurement errors in ITS recordings are always larger than in CWI recordings, which is in line with anticipation. Suppose we rule out negative correlation between measurement errors, as it would be hard to explain (an employment officer "punishing” an immigrant for lying to the IND?). Suppose we also rule out that the CWI recording has more measurement variance than true variance (a less inevitable assumption). Assume that the correlation will be somewhere in the range 0 to 0.7 . Then, the results from the negative root would be the more plausible. With correlation 0, true variance would be 8.38, ITS measurement variance 8.12 and CWI measurement variance 5.29 . With correlation at -0.7 , V would be 11.03, $\mathrm{V}_{\mathrm{eT}} 5.46$ and $\mathrm{V}_{\mathrm{eC}} 2.63$. The values imply that in the ITS records, the ratio $\mathrm{V} /\left(\mathrm{V}+\mathrm{V}_{\mathrm{eT}}\right)$ runs between 0.51 and 0.67 . In an OLS regression with years of education as single explanatory variable, this ratio would give the true regression coefficient as a proportion of the estimated coefficient. With more than one explanatory variable, all coefficients are biased downwards, but it is hard to determine the magnitudes (Wooldridge, 2002, 75). Unfortunately, in logit and probit regression the effect of measurement errors on estimated coefficients is unknown and one cannot assume analogy to linear regression ${ }^{3}$. The indication of substantial measurement errors in education is reason for concern. We will use the double measurement of education to check the reliability of our results.

Figure 1 Variances as a function of the correlation coefficient

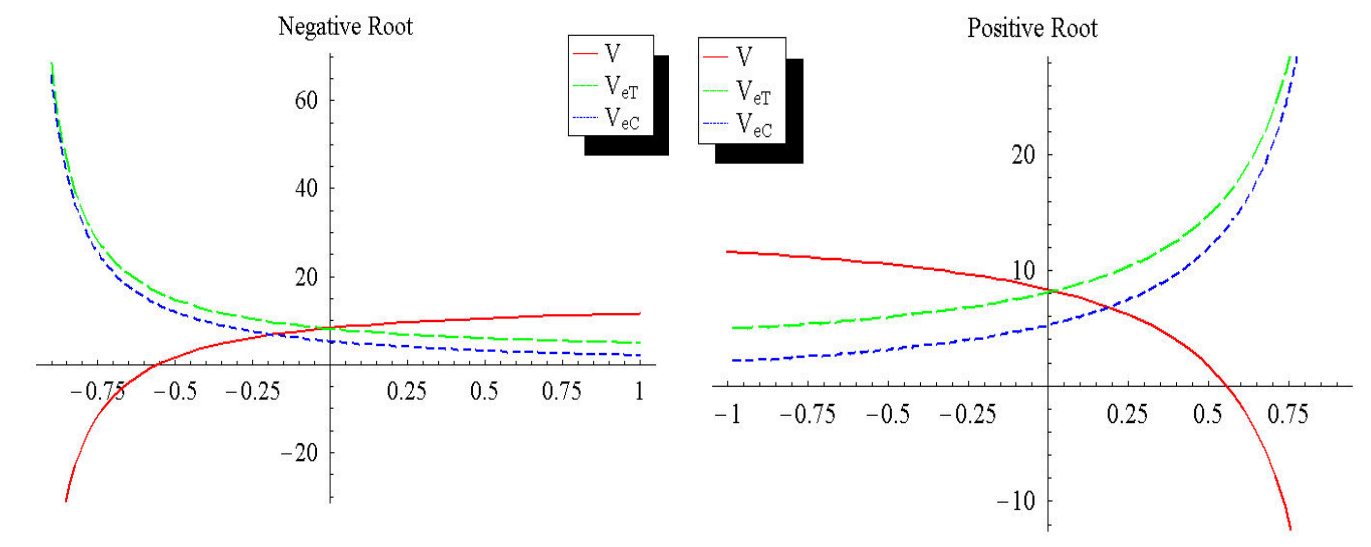

\footnotetext{
${ }^{2}$ We gratefully acknowledge the contribution of Adam Booij, who solved the equations with Mathematica and made the graphs.

${ }^{3}$ Private communication, professor J.S. Cramer, University of Amsterdam. As Cramer (2003, section 5.3) shows, omitted variables in linear regression affect precision of estimated coefficients, whereas in discrete models they lead to a downward bias.
} 


\section{Socio-economic status}

We have estimated the effect of education, and other variables, on socio-economic status, distinguishing three states: $Y_{i}=1$ if individual i is employed as employee or self-employed, $Y_{i}=2$ if person i does not work and receives some social benefit (unemployment, welfare), or $Y_{i}=3$ if individual i neither works nor receives a benefit (non-participating). Considering these three states, we have estimated a multinomial logit model using pooled data (with correction for standard errors for repeated observations per individual) since a panel estimation of a multinomial logit model is hard to construct and estimate ${ }^{4}$. Non-participation is defined as the reference category. Unemployment benefit and welfare are not distinguished, as the number of observations would become too small. The model has been estimated on all individuals who are present in 2000. We do not include refugees who have returned before 2000, or apply correction for such attrition. As noted above, among those admitted permanently (with an A-status) no one leaves and among those admitted temporarily, departures are exogenous, dictated by the political situation in their homeland.

Admitted immigrants have identical entitlements to social security benefits as native Dutch. But unemployment benefits are conditional on work history, which will disqualify immigrants in the early years after arrival. Social assistance does not depend on length of stay in the Netherlands, but is means-tested at the household level, and may disqualify marital partners or children (although the level of the benefit will depend on household composition). Refugees are provided shelter, food and a small amount of cash while their application is in process.

Formally, individual $i$ 's contribution to the likelihood function in state $j$ is

$$
P\left(Y_{i}=j \mid X_{i}\right)=\frac{e^{X_{i} \beta_{j}}}{1+\sum_{k=1}^{3} e^{X_{i} \beta_{k}}}
$$

where $X_{i}$ is a vector of explanatory variables; $\beta_{j}$ is a vector of coefficients, varying with three alternative outcomes and the coefficients for reference outcome 3 (nonparticipation) are normalized to zero. Since the estimated coefficients of a multinomial logit model are difficult to interpret directly, we report relative risk ratios as well ${ }^{5}$.

In Table 5, we report estimation results for the probability to work in the most extended specification. We control for cohort effects with dummies for year of arrival, and note that even though we also include the time profile of years since

\footnotetext{
${ }^{4}$ We have also estimated two sets of random effect panel logit models, with work versus non-work, benefits versus non-benefits, and work versus non-participation, benefits versus non-participation. The key conclusions are similar.

${ }^{5}$ The relative risk ratio has the probability that $Y=j$ relative the probability that $Y=3$, the base category, for given values of $\mathrm{X}$, in the denominator; the numerator has the same ratio when a particular variable in $\mathrm{X}$ is raised by one unit.
} 
migration (YSM), earlier arrivals do better. Differences between countries of origin are marked. For some countries, there are differences in level only, for other countries the interactions between country dummy and years since migration are also significant. We will return to country effects in section 6. Among the residential locations, Rotterdam and The Hague stand out with lower probability of employment. Age at arrival has a negative effect ${ }^{6}$, women are less likely to work than men. We have also considered the effect of the situation in the year after our observation interval. Those who will be naturalized in 2001 are more likely to work, those who will then have returned (or administratively removed) are less likely to work. The latter result hints at selectivity in return migration, in spite of our earlier remarks. Undoc years have a positive effect: refugees who have been in the Netherlands as undocumented workers before reporting to IND have higher probability to work. This is as anticipated: as undocumented workers they will mostly have worked, and effectively this adds experience to their years since migration. Statuswait has a negative effect. Spending more time in the application procedure reduces the probability to work, even after controlling for the other duration variables.

Years since migration YSM, i.e. time elapsed since registration in the population register GBA, has a monotonic positive effect on the probability to work, as one might expect We estimated a cubic function for years since migration to obtain maximum flexibility, although this cannot be extrapolated very far, as we only estimate over a five years interval. We have plotted the profile in Figure 2.

Figure 2 Probability of employment and benefit status over time spent in the Netherlands (years since migration YSM)

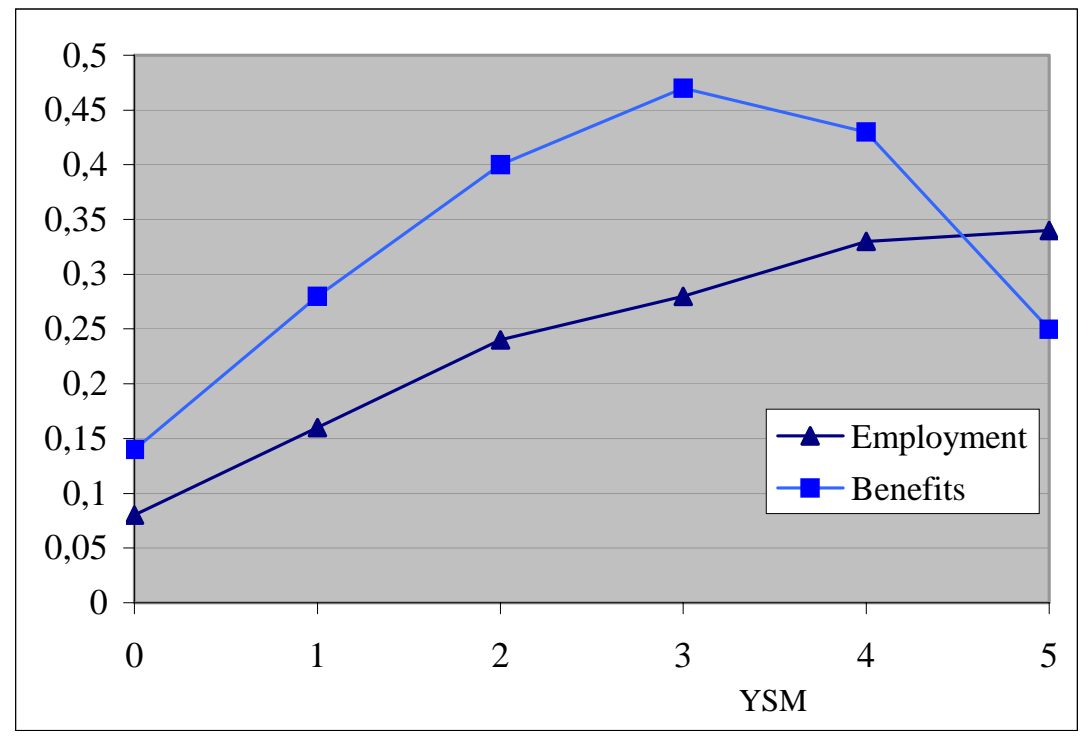

Our special interest is in the effect of home country schooling. Generally, there is a positive effect of schooling on the probability to work. Considering magnitudes and significance levels, it seems one may distinguish three steps: less than basic education, basic up to secondary general, secondary vocational and higher. The probability to work increases markedly between steps and is quite similar within the steps. Interestingly, and perhaps not surprisingly, the effect of secondary level

\footnotetext{
${ }^{6}$ Adding a quadratic for age was immaterial for our results (it was mostly insignificant).
} 
schooling is split: secondary vocational education has a stronger effect on the probability to work than secondary general education. This suggests that vocational skills are directly transferable, whereas general academic skills are not. Within the highest step, the effect of education diminishes slightly, though not significantly. Before checking the reliability of the results for education we will discuss the results for benefit recipient status.

The probability to receive a social benefit differs by country of origin, increases for more recent arrival cohorts, is higher for older and married individuals but not different for women, between cities is highest in Amsterdam. Undocyears has a positive, statuswait a negative effect. Refugees who are no longer present in 2001 have lower probability of recipient status, refugees who have become naturalized in 2001 have higher probability; these results also indicate that individuals who have less integrated into Dutch society are more likely to leave. Years since migration has a positive effect that peaks after 3 years (Figure 2). The effect is initially positive, as refugees have to build up entitlements. Later, the profile declines as the immigrants find jobs.

The effect of education is essentially a single jump at extended primary education. Individuals with education below that level have the same probability of receiving benefits, individuals with that level or higher share a significantly higher benefit probability. One might perhaps have anticipated that the effect would be negative, as those with a higher education would be better able to find a job. It is not quite clear how to interpret this unanticipated finding. It may be a reflection of the build-up of benefit entitlement with work history, as the results for work and benefit are to some extent parallel: higher education leads to higher probability of work, which also leads to increases in the probability to be eligible for social benefits.

Table 5. Multinomial logit estimates for employment and benefit status

\begin{tabular}{|c|c|c|c|c|c|c|}
\hline & \multicolumn{3}{|c|}{ Employment } & \multicolumn{3}{|c|}{ Benefits } \\
\hline & Coeff. & Std. Err & RRR & Coeff. & Std. Err & RRR \\
\hline Age & $-0.03 * \star \star$ & 0.003 & 0.97 & 0.05 *** & 0.003 & 1.05 \\
\hline Woman & $-1.29 * \star \star$ & 0.054 & 0.28 & 0.01 & 0.051 & 1.01 \\
\hline YSM & 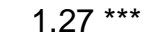 & 0.094 & 3.54 & $1.24^{* \star *}$ & 0.091 & 3.46 \\
\hline YSM2 & $-0.12 * * *$ & 0.028 & 0.89 & $-0.25 * \star *$ & 0.023 & 0.78 \\
\hline YSM3 & $0.01 * *$ & 0.004 & 1.01 & $0.02 * \star *$ & 0.003 & 1.02 \\
\hline Ysmlraq & -0.09 & 0.075 & 0.91 & 0.00 & 0.077 & 1.00 \\
\hline YsmSomali & $-0.28 * \star \star$ & 0.085 & 0.75 & 0.06 & 0.091 & 1.06 \\
\hline YsmChin & $0.54 * \star \star$ & 0.145 & 1.71 & $0.34^{* \star *}$ & 0.112 & 1.41 \\
\hline YsmAfgh & 0.15 * & 0.079 & 1.16 & $0.52 * * \star$ & 0.082 & 1.69 \\
\hline YsmSudan & 0.16 & 0.110 & 1.18 & $0.32 * * *$ & 0.123 & 1.38 \\
\hline YsmYugos & 0.04 & 0.080 & 1.04 & -0.05 & 0.094 & 0.96 \\
\hline YsmSovU & -0.07 & 0.096 & 0.93 & -0.23 ** & 0.093 & 0.79 \\
\hline $\begin{array}{l}\text { YsmOther } \\
\text { arrival95 (reference) }\end{array}$ & -0.09 & 0.071 & 0.92 & -0.18 ** & 0.079 & 0.83 \\
\hline arrival96 & $0.42 * \star * *$ & 0.084 & 1.52 & $0.44^{* \star *}$ & 0.083 & 1.56 \\
\hline arrival97 & $0.65 * \star *$ & 0.094 & 1.92 & 0.18 ** & 0.093 & 1.20 \\
\hline arrival98 & $0.64^{\star \star \star}$ & 0.101 & 1.89 & -0.56 *** & 0.104 & 0.57 \\
\hline arrival99 & 0.15 & 0.145 & 1.16 & $-0.87 * * \star$ & 0.149 & 0.42 \\
\hline $\begin{array}{l}\text { arrival00 } \\
\text { No education (reference) }\end{array}$ & 0.44 & 0.316 & 1.55 & -0.49 & 0.333 & 0.61 \\
\hline
\end{tabular}




\begin{tabular}{|c|c|c|c|c|c|c|}
\hline edu1_3y & 0.11 & 0.171 & 1.12 & 0.20 & 0.184 & 1.22 \\
\hline edu4_5y & 0.20 & 0.155 & 1.23 & 0.22 & 0.148 & 1.24 \\
\hline EduPrim & $0.38 * \star \star$ & 0.135 & 1.46 & 0.15 & 0.137 & 1.16 \\
\hline EduPrim_ext & $0.53 * \star \star$ & 0.119 & 1.70 & $0.49 * \star \star$ & 0.117 & 1.64 \\
\hline eduSec_gen & $0.45 * \star \star$ & 0.120 & 1.56 & $0.48^{\star * \star}$ & 0.114 & 1.62 \\
\hline eduSec_voc & $0.79 * \star \star$ & 0.165 & 2.21 & 0.44 *** & 0.156 & 1.55 \\
\hline EduHigh_some & $0.76 * \star \star$ & 0.169 & 2.13 & $0.39 \star \star \star ~$ & 0.169 & 1.48 \\
\hline EduHigh & $0.67 * \star \star$ & 0.128 & 1.94 & $0.47^{* \star \star}$ & 0.119 & 1.60 \\
\hline EduMiss & $0.38^{* \star *}$ & 0.104 & 1.47 & 0.14 & 0.100 & 1.15 \\
\hline Iraq & $1.06 * \star *$ & 0.197 & 2.89 & 0.16 & 0.186 & 1.18 \\
\hline Somalia & $1.13^{\star \star \star}$ & 0.223 & 3.10 & -0.14 & 0.232 & 0.87 \\
\hline China & $-1.20 * \star *$ & 0.382 & 0.30 & -0.39 & 0.268 & 0.68 \\
\hline Afghan & $1.09 * * *$ & 0.196 & 2.97 & $-0.45^{* *}$ & 0.189 & 0.64 \\
\hline Sudan & $0.99 * \star \star$ & 0.231 & 2.68 & 0.10 & 0.234 & 1.11 \\
\hline Yugoslavia & $0.76 * \star *$ & 0.213 & 2.14 & -0.07 & 0.216 & 0.94 \\
\hline SovietUni & 0.32 & 0.240 & 1.38 & 1.10 *** & 0.207 & 3.00 \\
\hline $\begin{array}{l}\text { OtherC } \\
\text { Iran (reference) }\end{array}$ & 0.20 & 0.200 & 1.22 & 0.22 & 0.191 & 1.24 \\
\hline A_Status & 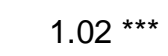 & 0.066 & 2.78 & $2.47^{* \star *}$ & 0.062 & 11.85 \\
\hline AMA & 0.03 & 0.099 & 1.03 & $1.86^{* \star *}$ & 0.114 & 6.43 \\
\hline Undocyears & 0.56 *** & 0.035 & 1.75 & $0.15^{* * *}$ & 0.036 & 1.17 \\
\hline Statuswait & $-0.68 * \star *$ & 0.093 & 0.51 & -0.31 *** & 0.077 & 0.73 \\
\hline Naturalised & $0.82 * \star * *$ & 0.075 & 2.27 & $0.81 * * *$ & 0.075 & 2.25 \\
\hline Returned & $-1.11 * \star \star$ & 0.189 & 0.33 & 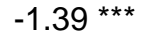 & 0.278 & 0.25 \\
\hline Married & -0.14 ** & 0.056 & 0.87 & $0.54 * \star *$ & 0.053 & 1.72 \\
\hline Amsterdam & 0.16 & 0.096 & 1.17 & $0.68^{* \star *}$ & 0.100 & 1.97 \\
\hline Rotterdam & $-0.44 * \star \star *$ & 0.113 & 0.65 & 0.10 & 0.108 & 1.10 \\
\hline DenHaag & -0.26 ** & 0.110 & 0.77 & 0.22 ** & 0.102 & 1.24 \\
\hline Utrecht & 0.18 & 0.159 & 1.20 & 0.07 & 0.200 & 1.07 \\
\hline Constant & $-3.45 * \star *$ & 0.252 & 0.03 & $-5.03 * \star *$ & 0.242 & 0.01 \\
\hline $\mathrm{N}$ & 31323 & & & & & \\
\hline Log Likelihood & -22103 & & & & & \\
\hline Chi-Square & 7588 & & & & & \\
\hline AIC statistic & 44395 & & & & & \\
\hline
\end{tabular}

(Standard errors adjusted for clustering on person ID)

RRR: Relative Risk Ratio

As we are specifically interested in the effects of homeland education, we have concentrated our analysis of reliability on the effects of education. We have made separate estimations on sub-samples, and we attempted to allow for the reliability of recorded level of education. In Table $6 \mathrm{a}$ and $6 \mathrm{~b}$, we present estimates on five subsamples: arrivals 1995, arrivals 1998-2000, men, women, excluded if education missing. A generally positive effect of level of education on the probability of employment but without university education ranking on top, is confirmed in all these regressions. The estimates confirm a strong positive effect of secondary vocational education. The parabolic effect of education is more noticeable in the 1995 cohort than in the 1998-2000 cohort. This is rather surprising, as it suggests that lagging employment probability of the university educated increases over time; one might have anticipated the reverse effect. The results for the probability to receive social benefits estimated on sub-samples also basically repeat the findings for the full sample: there is no monotonic relationship between benefit recipient status and level of education. The relatively stronger effects for women compared to those for men 
lend further support to the interpretation that increased probability of receiving benefits reflects the build-up of eligibility rights, as women probably have a longer period of transition to labour market activity after settling as an immigrant.

Table 6a. Testing on sub-samples: Employment

\begin{tabular}{|c|c|c|c|c|c|c|}
\hline Variable & Mod. I & Mod. II & Mod. III & Mod. IV & Mod. V & Mod. VI \\
\hline & Coefficients & & & & & \\
\hline edu1_3y & 0.11 & 0.07 & -0.40 & 0.08 & 0.06 & 0.12 \\
\hline edu4_5y & 0.20 & 0.14 & 0.13 & 0.03 & 0.42 & 0.21 \\
\hline EduPrim & $0.38^{\star \star \star}$ & $0.50 *$ & -0.14 & $0.40^{\star *}$ & 0.17 & $0.39 * * *$ \\
\hline EduPrim_ext & $0.53^{\star \star \star}$ & $0.63^{\star \star}$ & 0.32 & $0.41^{\star \star \star}$ & $0.68^{\star \star \star}$ & $0.54^{\star * *}$ \\
\hline eduSec_gen & $0.45^{\star \star \star}$ & $0.75^{\star \star \star}$ & $0.51^{* *}$ & $0.31^{\star *}$ & $0.72^{\star \star \star}$ & $0.46^{\star \star *}$ \\
\hline eduSec_voc & 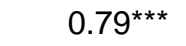 & $1.37^{\star \star \star}$ & 0.41 & $0.61^{\star \star \star}$ & $1.18^{\star \star \star}$ & $0.72^{\star \star *}$ \\
\hline EduHigh_some & $0.76^{\star \star \star}$ & $0.87^{\star *}$ & 0.48 & $0.48^{\star \star}$ & $1.28^{\star \star \star}$ & $0.74^{\star \star \star}$ \\
\hline EduHigh & $0.67^{\star \star \star}$ & $0.83^{\star \star *}$ & $0.69 * \star \star *$ & $0.50^{\star \star \star}$ & $0.97^{\star \star \star}$ & $0.63^{\star \star \star}$ \\
\hline EduMiss & $0.38^{\star \star \star}$ & $0.44^{\star \star}$ & $0.35^{\star}$ & $0.26 * \star$ & $0.48 * \star$ & \\
\hline
\end{tabular}

Table 6b. Testing on sub-samples: Benefits

\begin{tabular}{|c|c|c|c|c|c|c|}
\hline Variable & Mod. I & Mod. II & Mod. III & Mod. IV & Mod. V & Mod. VI \\
\hline & Coefficients & & & & & \\
\hline edu1_3y & 0.20 & -0.32 & 0.44 & 0.11 & 0.27 & 0.21 \\
\hline edu4_5y & 0.22 & 0.44 & 0.08 & -0.02 & $0.46^{\star \star}$ & 0.23 \\
\hline EduPrim & 0.15 & 0.34 & -0.10 & 0.31 & -0.10 & 0.14 \\
\hline EduPrim_ext & $0.49 * \star \star$ & $0.83^{\star \star *}$ & 0.22 & 0.40 ** & $0.57^{\star \star *}$ & 0.50 *** \\
\hline eduSec_gen & $0.48^{\star \star \star}$ & $0.85^{\star \star \star}$ & 0.11 & $0.41^{* *}$ & $0.54^{\star * *}$ & $0.47^{\star * *}$ \\
\hline eduSec_voc & $0.44^{\star \star *}$ & $0.94^{\star * \star}$ & -0.64 & $0.39 *$ & 0.39 & $0.46^{\star * \star}$ \\
\hline EduHigh_some & $0.39 * \star$ & 0.53 & 0.07 & 0.08 & $0.74^{\star \star *}$ & $0.39 * \star$ \\
\hline EduHigh & $0.47^{\star \star \star}$ & $0.70^{\star \star \star}$ & 0.08 & $0.38^{\star *}$ & $0.54^{\star \star \star}$ & $0.48^{\star * \star}$ \\
\hline EduMiss & 0.14 & 0.26 & 0.10 & 0.05 & 0.20 & \\
\hline
\end{tabular}

The models are estimated with the same variables as in table 5 in addition to the education variables presented in table $6 \mathrm{a}$ and $6 \mathrm{~b}$ but the rest of coefficients are not presented here.

Model I: Reference (full sample) Model IV: Men

Model II: Arrivals 1995

Model V : Women

Model III: Arrivals 1998-2000

Model VI: Deleted if education missing

To test the sensitivity of our results for the reliability of recorded education, we have made selections based on the combination of ITS and CWI records (Table 7), by discarding "unreliable" recordings of education. We defined "unreliable" as clear mismatch in the two measurements. The first selection rule we applied, reported under model II, is the following:

ITS primary or less: accepted if CWI classification Basic

ITS extended primary and secondary: accepted if CWI lower or intermediate

ITS secondary vocational, some tertiary: accepted if CWI intermediate or higher vocational ITS higher: accepted if CWI university

Due to the difference in the two classification systems this is not a strict criterion for a perfect match, so some noise is inevitably left. We therefore also used as an 
alternative selection rule that the classifications should agree on the level of primary/secondary/tertiary. We then estimated two specifications: the usual specification with all ITS categories (Model III) and a specification with three levels only (primary/secondary/tertiary; Model IV). By requiring a credible match between ITS and CWI classification, we reduce the sample to those observations for which CWI classification is available. This is quite restrictive and certainly not random. Therefore we also re-estimated the non-restricted versions on the sub-sample for which both ITS and CWI education levels are available. This is reported as Model I.

The restriction of the sample to individuals with observations from ITS and from CWI essentially has no substantial effect (compare the first column from Table 7 with the first column of Table 6). Further restrictions of the dataset also leave the key conclusion unaffected. The probability of employment increases in steps with the level of education but is not highest for the highest level of education. The probability of receiving benefit is not monotonically declining in level of education, but if anything, is closer to a parabolic relationship. If we restrict education levels to (matching) primary, secondary and tertiary only, we find that employment and benefit probabilities are equal for secondary and tertiary educated individuals, and above the probabilities for those with primary education only.

Tabel 7a Restricting the sample to matching education: Employment

\begin{tabular}{lcccc}
\hline Variable & Model I & Model II & Model III & Model IV \\
\hline & Coefficients & & & \\
\cline { 2 - 5 } edu1_3y & 0.29 & $0.70^{\star \star}$ & $0.70^{\star \star}$ & \\
edu4_5y & 0.33 & $0.58^{\star \star}$ & $0.57^{\star \star}$ & \\
EduPrim & $0.51^{\star \star \star}$ & $0.78^{\star \star \star}$ & $0.66^{\star \star}$ & \\
eduPrim_ext & $0.68^{\star \star \star}$ & $0.94^{\star \star \star}$ & $0.95^{\star \star \star}$ & \\
eduSec_gen & $0.66^{\star \star \star}$ & $0.85^{\star \star \star}$ & $0.93^{\star \star \star}$ & \\
eduSec_voc & $0.83^{\star \star \star}$ & $1.06^{\star \star \star}$ & $1.62^{\star \star \star}$ & \\
eduHigh_some & $0.97^{\star \star \star}$ & $1.08^{\star \star \star}$ & $1.53^{\star \star \star}$ & \\
EduHigh & $0.83^{\star \star \star}$ & $1.04^{\star \star \star}$ & $1.12^{\star \star \star}$ & \\
edulTSsec & & & & $0.62^{\star \star \star}$ \\
edulTSter & & & & $0.65^{\star \star \star}$ \\
\hline
\end{tabular}

Table 7b: Restricting the sample to matching education: Benefits

\begin{tabular}{|c|c|c|c|c|}
\hline Variable & Model I & Model II & Model III & Model IV \\
\hline & Coefficients & & & \\
\hline Edu1_3y & 0.29 & $0.52^{*}$ & 0.31 & \\
\hline Edu4_5y & $0.33^{*}$ & $0.36^{*}$ & 0.27 & \\
\hline eduPrim & 0.14 & 0.25 & 0.22 & \\
\hline eduPrim_ext & $0.50^{* * *}$ & $0.52^{\star \star \star}$ & $0.35^{\star}$ & \\
\hline eduSec_gen & $0.52^{\star \star \star}$ & $0.47^{\star \star \star}$ & $0.46^{\star \star \star}$ & \\
\hline eduSec_voc & $0.42^{\star \star}$ & $0.43^{\star \star}$ & $0.60 * \star$ & \\
\hline eduHigh_some & $0.46^{\star \star}$ & $0.59^{\star \star}$ & 0.42 & \\
\hline eduHigh & $0.49 * \star \star$ & $0.50 * \star \star$ & $0.45^{\star \star}$ & \\
\hline edulTSsec & & & & $0.27^{\star *}$ \\
\hline edulTSter & & & & $0.29 *$ \\
\hline
\end{tabular}

The models are estimated with the same variables as in table 5 in addition to the education variables presented in table $7 \mathrm{a}$ and $7 \mathrm{~b}$ but the rest of coefficients are not presented here. 


\section{Earnings}

In Table 8, we present estimates for earnings for employees, i.e. individuals for whom labour earnings is the most important source of income during the year. It is the natural logarithm of annual labour income divided by weeks worked and deflated by cost-of-living (base year 1995). Thus, there is some unknown measurement error as hours per week may vary over individuals, and because individuals may have some benefit income on top of labour earnings. We have estimated a panel GLS model with random effects. The basic specification given in column (1) has been found after testing for several interaction effects and alternative specifications that will be pointed out as we discuss the main findings below. Among the alternatives, we have separate estimates for men and women and separate estimates by year of arrival. The latter distinction has been made, as before, to check if certain effects become more pronounced as immigrants have been in The Netherlands for a longer period of time ${ }^{7}$.

Table 8:. Panel GLS random effect estimations

\begin{tabular}{|c|c|c|c|c|c|c|}
\hline Weekly wages & Model I & Model II & Model III & Model IV & $\begin{array}{r}\text { Model } \\
\mathrm{V}\end{array}$ & $\begin{array}{r}\text { Model } \\
\text { VI }\end{array}$ \\
\hline Age & $0.04^{\star \star \star}$ & $0.06^{\star \star \star}$ & $0.03^{\star \star \star}$ & $0.04^{\star \star \star}$ & $0.05^{\star \star \star}$ & $0.04^{\star * \star}$ \\
\hline Woman & $-0.46^{\star \star \star}$ & $-0.43^{\star * \star}$ & $-0.30 * \star \star$ & & & $-0.43^{\star * *}$ \\
\hline YSM & $0.26^{\star \star \star}$ & $0.37^{* \star *}$ & $0.24^{\star \star}$ & $0.26^{\star \star \star}$ & $0.22^{\star \star}$ & $0.21^{\star \star *}$ \\
\hline arrival96 & $0.16^{\star \star \star}$ & & & $0.16^{\star \star \star}$ & 0.09 & $0.13^{\star \star}$ \\
\hline arrival97 & $0.18^{\star \star \star}$ & & & $0.17^{\star \star \star}$ & 0.13 & 0.11 \\
\hline arrival98 & $0.18^{\star \star *}$ & & & $0.16^{\star \star}$ & 0.19 & 0.03 \\
\hline arrival99 & -0.09 & & & -0.11 & -0.14 & -0.20 \\
\hline arrival00 & $0.65^{\star \star}$ & & & -0.10 & $1.17^{\star \star}$ & $0.63^{\star}$ \\
\hline edu1_3y & 0.00 & $0.62^{\star \star *}$ & 0.15 & -0.07 & 0.27 & 0.00 \\
\hline edu4_5y & $0.21^{*}$ & $0.45^{\star \star}$ & 0.16 & 0.16 & 0.26 & $0.23^{\star \star}$ \\
\hline EduPrim & $0.28 * \star \star$ & $0.49 * \star \star$ & 0.11 & $0.31^{\star \star *}$ & 0.00 & $0.28^{\star \star \star}$ \\
\hline eduPrim_ext & $0.36^{\star \star \star}$ & $0.74^{\star \star \star}$ & $0.38 *$ & $0.32^{\star \star *}$ & $0.41^{\star \star}$ & $0.39 * * *$ \\
\hline eduSec_gen & $0.31^{* \star *}$ & $0.51^{\star \star \star}$ & 0.17 & $0.32^{\star \star *}$ & 0.10 & $0.34^{\star \star \star}$ \\
\hline eduSec_voc & $0.21^{*}$ & $0.45^{\star \star}$ & -0.33 & 0.18 & 0.31 & $0.21^{*}$ \\
\hline eduHigh_some & 0.18 & 0.20 & 0.22 & 0.18 & 0.06 & $0.23^{*}$ \\
\hline EduHigh & $0.20 * *$ & 0.18 & 0.21 & $0.21^{* \star}$ & -0.03 & $0.24^{\star * \star}$ \\
\hline EduMiss & $0.13^{\star}$ & 0.20 & 0.28 & 0.14 & -0.01 & \\
\hline Iraq & $0.35^{\star \star}$ & 0.13 & 0.27 & $0.41^{\star \star}$ & 0.08 & 0.08 \\
\hline Somalia & $0.65^{\star \star \star}$ & $0.61^{\star *}$ & $0.75^{\star \star}$ & $0.66^{\star \star \star}$ & 0.50 & $0.51^{\star \star}$ \\
\hline China & -0.23 & -0.56 & 0.53 & -0.10 & -0.79 & -0.51 \\
\hline Afghan & $0.29 * \star$ & 0.18 & 0.31 & $0.35^{\star \star}$ & 0.03 & 0.14 \\
\hline Sudan & $0.61^{* \star \star}$ & $1.40^{\star \star \star}$ & 0.17 & $0.65^{\star \star *}$ & 0.75 & $0.53^{\star *}$ \\
\hline Yugoslavia & $0.61^{\star \star \star}$ & 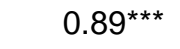 & 0.27 & $0.61^{\star \star \star}$ & $0.55^{\star}$ & $0.46^{\star \star}$ \\
\hline SovietUni & $0.38^{*}$ & 0.30 & -0.19 & 0.26 & 0.44 & 0.35 \\
\hline OtherC & $0.51^{\star \star \star}$ & $0.88^{\star \star \star}$ & 0.30 & $0.48^{\star \star *}$ & $0.63^{\star \star}$ & 0.33 \\
\hline A_Status & 0.02 & -0.03 & 0.02 & 0.06 & -0.10 & 0.00 \\
\hline Ysmlraq & -0.05 & -0.02 & -0.05 & -0.04 & -0.04 & 0.06 \\
\hline YsmSomali & -0.08 & -0.12 & -0.13 & -0.05 & -0.15 & -0.04 \\
\hline YsmChin & $0.17^{*}$ & 0.20 & -0.37 & 0.10 & $0.44^{\star *}$ & $0.27^{\star *}$ \\
\hline YsmAfgh & -0.03 & -0.01 & -0.09 & -0.04 & 0.02 & 0.03 \\
\hline YsmSudan & -0.02 & $-0.28^{\star \star \star}$ & 0.11 & -0.01 & -0.18 & 0.04 \\
\hline
\end{tabular}

\footnotetext{
${ }^{7}$ We have also estimated interaction effects with years-since-migration; these were generally insignificant.
} 


\begin{tabular}{|c|c|c|c|c|c|c|}
\hline YsmYugos & $-0.08^{*}$ & $-0.21^{\star \star \star}$ & -0.12 & -0.07 & -0.12 & -0.02 \\
\hline YsmSovU & -0.03 & 0.02 & 0.15 & 0.03 & -0.10 & 0.00 \\
\hline YsmOther & -0.05 & $-0.20^{* *}$ & -0.13 & -0.03 & -0.10 & 0.02 \\
\hline AMA & 0.10 & $0.32^{\star \star}$ & $-0.67^{\star *}$ & 0.12 & -0.11 & 0.16 \\
\hline Undocyears & $0.13^{\star \star \star}$ & $0.15^{\star \star \star}$ & 0.05 & $0.14^{\star \star \star}$ & 0.08 & $0.12^{\star \star \star}$ \\
\hline Statuswait & $-0.14^{\star \star \star}$ & -0.16 & -0.09 & $-0.19^{\star \star \star}$ & -0.04 & $-0.14^{\star \star}$ \\
\hline Married & $0.19^{\star \star \star}$ & $0.19 * \star$ & 0.11 & $0.18^{\star \star \star}$ & $0.19^{\star *}$ & $0.23^{\star \star *}$ \\
\hline Amsterdam & 0.08 & $0.28^{\star \star}$ & -0.12 & 0.03 & $0.46^{\star \star \star}$ & 0.02 \\
\hline Rotterdam & $0.14^{*}$ & 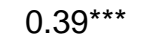 & 0.31 & 0.13 & 0.16 & $0.22^{\star \star}$ \\
\hline DenHaag & $0.16^{\star \star}$ & 0.26 & 0.26 & $0.15^{*}$ & 0.29 & 0.08 \\
\hline Utrecht & 0.03 & 0.03 & -0.10 & 0.02 & 0.17 & -0.02 \\
\hline Constant & $2.36^{\star \star \star}$ & $1.56^{\star \star \star}$ & $3.03^{\star \star \star}$ & $2.37^{\star \star \star}$ & $2.10^{\star \star \star}$ & $2.60^{\star \star \star}$ \\
\hline$\sigma_{\mathrm{u}}$ & 0.70 & 0.69 & 0.37 & 0.70 & 0.66 & 0.70 \\
\hline$\sigma_{\mathrm{e}}$ & 0.71 & 0.61 & 1.06 & 0.71 & 0.71 & 0.67 \\
\hline$\rho$ & 0.49 & 0.56 & 0.11 & 0.50 & 0.46 & 0.52 \\
\hline $\mathrm{N}$ & 5933 & 1424 & 1045 & 4762 & 1171 & 3088 \\
\hline Average $n_{i}$ & 1.6 & 1.9 & 1.2 & 1.6 & 1.5 & 1.6 \\
\hline R-sq Within & 0.10 & 0.23 & 0.01 & 0.10 & 0.10 & 0.12 \\
\hline Between & 0.24 & 0.40 & 0.13 & 0.20 & 0.32 & 0.25 \\
\hline Overall & 0.25 & 0.40 & 0.12 & 0.20 & 0.31 & 0.26 \\
\hline chi2 & 1502.8 & 697.3 & 125.97 & 951.61 & 399.6 & 828.26 \\
\hline
\end{tabular}

$\sigma_{u}$ is panel-level standard deviation

$\sigma_{e}$ is standard deviation of $\varepsilon_{i t}$

$\rho$ is fraction of total variance due to the panel-level variance component

$\mathrm{n}_{\mathrm{i}}$ is the number of times individual $\mathrm{i}$ is observed in the sample

$\begin{array}{ll}\text { Model I } & \text { : basic specification } \\ \text { Model II } & \text { : arrivals 1995 (IND registration) } \\ \text { Model III } & \text { : arrivals 1998-2000 (IND registration) } \\ \text { Model IV } & \text { : men only } \\ \text { Model V } & \text { : women only } \\ \text { Model VI } & \text { : observations with education missing deleted }\end{array}$

The effect of age at arrival is fairly steep, with an annual growth rate of some $4 \%$. The result is quite robust across specifications, but it drops if we estimate separately for later arrival cohort, suggesting that the disentanglement of age and years since migration is less than perfect. There is a strong and very substantial positive direct effect of years since migration. Higher orders of age and years since migration have also been tested, but they were not significant. The effect of arrival year is fairly uniform for the first three years. The strong positive effect for the latest cohort may be a selectivity effect: these are refugees who can work right in their first year of arrival, which is quite unusual. Eliminating the dummies for arrival years has no effect on the estimates for age or years since migration.

As the overall regression indicates, women earn about half of what comparable men earn, which is a striking difference. Several effects are essentially the same for men and women: age, years since migration, marital status. The rankings by country are very similar, suggesting that country effects relate to real underlying differences in human capital that immigrants bring.. Just as for men, the coefficients on years since migration do not differ significantly between countries. In fact, significance levels are 
even lower, and we can only conclude that in those early years after arrival the speed of assimilation for women is identical across source countries. The only exception is Chinese women, with a strong positive effect.

The differences in status are not significant, except for AMA's if we split: in the youngest cohort, they are far behind, in the oldest cohort they have a premium of over $30 \%$. This is a fantastic race through the earnings distribution. The effects of time elapsed before obtaining status are quite interesting. Years spent as undocumented worker add experience, but the pay-off is much less than the return to years since migration (however, accumulating undocumented years may also signal that the individual in fact is not a refugee but an economic migrant, as a convinced refugee would start the application procedure right away). Conversely, years spent waiting for a status reduces earnings, at about the same rate. ${ }^{8}$ These are substantial rates: a year of undocumented work adds $13 \%$ to earnings on top of the benefits from years since migration (the time scale has the same origin), another year of waiting reduces earnings by $14 \%$. The effects are located with men, as they are not significant for women. We have also tested for selection effects, by adding a dummy for immigrants who had returned by 2001. The coefficient is not significant, further supporting our claim that in this sample, selective return migration is not an issue.

Married immigrants earn more than singles, and remarkably, on average earnings are highest in The Hague, the seat of government. But if we split between men and women, we see that men still earn most in The Hague, but that women earn most in Amsterdam.

Education has an unexpected parabolic effect. Most coefficients are statistically significant. The returns peak for extended primary education. One might think that this reflects selectivity, as those with higher educations might be engaged in further education in the Dutch school system. But the results of employment and benefit status in Section 4 (Table 5) do not lend much support to that interpretation. Interaction of education with years since migration is insignificant for all levels of education. One might have thought that those with the highest education may have the steepest time profiles, because of complementarity between homeland education and the intensity and returns of investment in specific Dutch human capital (Duleep and Regets, 1999). But we did not find any significant interaction between schooling and years since migration. We will return to such issues in the next section.

In columns (2) and (3) we present results separately for early and late arrivals (the earliest and the latest that we can meaningfully define). (Arrival is measured by year of IND registration; individuals may have been in the country before that, so we still have variation on years since migration). The parabolic pattern of returns by education level is basically visible for the oldest and the youngest cohort, but precision is quite weak for the youngest. The oldest cohort have higher benefits from education than the youngest. It is quite remarkable that even for the oldest cohort, earnings drop for education levels beyond extended primary. There is no need to worry about effects of small sample size, as some $9 \%$ of the sample has higher education (for some countries, the percentage is well above 10, see Table 2). Also

\footnotetext{
${ }^{8}$ Note that statuswait covers time before YSM, while undocyears covers years parallel with YSM. YSM starts at GBA registration, statuswait is time spent in the Netherlands before GBA registration, undocyears is time spent since GBA registration.
} 
remarkable is the strong benefits for the least educated, some years primary, after 5 years in the Netherlands. Thus, benefits from education clearly increase with time spent in The Netherlands, but the pattern by level of education is surprising.

The parabolic effect of education that we found in the joint estimation is also visible in the results for men and women separately, but with some differences. For men, returns to education behave like a step function: zero if basic education has not been completed, some $35 \%$ for primary and extended primary, some $20 \%$ for the higher levels. For women, a single peak stands out, a significant $41 \%$ at extended primary education.

The core result on education is a non-monotonic effect on earnings. Highest earnings are consistently found for immigrants with educations in the middle of the distribution. Most remarkable is the consistent drop in earnings for immigrants with education beyond secondary. How robust is this result?

In column (5) of Table 8 we have reported estimation results for the case where we drop all observations where information on education is missing. This has no effect: whether we know education or not is immaterial for the estimation of the coefficients on the other variables. Covariances between education and other variables are not responsible for the result.

We have also made estimates with a selection on observations for reliability of the education variable, just as we did in the previous section for employment and benefit recipient status (Table 9). For ease of comparison we copied the basic specification from Table 8.

Table 9. Selecting on reliable measurement of education

\begin{tabular}{|c|c|c|c|c|c|c|}
\hline & $\begin{array}{l}\text { C1 from } \\
\text { T8 }\end{array}$ & Model I & Model II & Model III & Model IV & Model V \\
\hline edu1_3y & 0.00 & 0.07 & 0.03 & 0.16 & & \\
\hline edu4_5y & $0.21^{*}$ & $0.23^{*}$ & 0.17 & 0.10 & & \\
\hline eduPrim & $0.28^{\star \star \star}$ & $0.27^{\star \star}$ & $0.29 * \star$ & $0.40^{* *}$ & & \\
\hline eduPrim_ext & $0.36^{\star \star \star}$ & $0.32^{\star \star *}$ & $0.31^{\star \star}$ & $0.25^{\star}$ & & \\
\hline eduSec_gen & $0.31^{\star \star *}$ & $0.27^{\star \star \star}$ & $0.27^{\star \star}$ & 0.20 & & \\
\hline eduSec_voc & $0.21^{*}$ & $0.39 * * *$ & $0.41^{* * *}$ & $0.35^{\star \star}$ & & \\
\hline eduHigh_some & 0.18 & 0.16 & 0.26 & $0.38^{\star *}$ & & \\
\hline eduHigh & 0.20 ** & $0.27^{\text {** }}$ & $0.28^{\star \star}$ & $0.26^{*}$ & & \\
\hline edumissing & $0.13^{*}$ & & & & & \\
\hline edulTSsec & & & & & 0.06 & \\
\hline edulTSter & & & & & 0.06 & \\
\hline eduSec_gen & & & & & & 2.91 \\
\hline eduSec_voc & & & & & & -3.01 \\
\hline eduHigh_some & & & & & & 0.12 \\
\hline eduHigh & & & & & & 0.65 \\
\hline eduMissing & & & & & & 1.07 \\
\hline
\end{tabular}

The models are estimated with the same variables as in table 8 in addition to the education variables presented in table 9 but the rest of coefficients are not presented here.

The effect of selective observation by the Employment Service is remarkably small. The estimated coefficients differ somewhat between the full sample and the restricted 
sample used for Model I, but in a qualitative sense, the conclusions are not affected. The coefficients on education are very similar, except for secondary vocational education. Immigrants with that education who visit the Employment Service are much more successful than an average immigrant with that education. Of course we cannot say whether this is due to the positive influence of the Employment Service, or to higher unobserved quality of those who visit. From inspecting results for models II and III we can clearly conclude that our key conclusion on education survives: immigrants with higher education do not earn more than immigrants with lower education. In the period we observe, education acquired at home does not pay off in the Dutch labour market. Under reliability restriction II, the earnings levels for immigrants are identical for all education levels beyond some primary, with the exception of secondary vocational. Under reliability restriction III, there is equal pay for primary education, secondary vocational and some higher level education, with all other levels earning less. Model IV is even more outspoken: there is no earnings difference between immigrants with primary, secondary or tertiary education!

Results from Instrumental Variable regression are reported as model V. We used the CWI measure of education as an instrument for the ITS measure of education. As we know that CWI education correlates with ITS education and as we may assume that CWI education does not affect the disturbances in an earnings function that would include true education CWI education is a good instrument (Wooldridge, 2002, 83). We cannot maintain the same classification of education, as the number of instruments cannot be smaller than the number of instrumented variables. With Instrumental Variables, we find essentially the same result: there is no monotonic increase of earnings with education level, higher educations do not lead to higher pay. These results are robust, no matter whether we use pooled OLS, random effect GLS, or restriction to observations in 2000 only (the table only shows random effect GLS results).

We have considered estimation of earnings functions corrected for participation using Heckman's two-step procedure. A priori we had reservations because not many variables are available and credible exclusion restrictions are hard to determine. We estimated a wage equation for the pooled sample with correction of standard errors for repeated observations and separate for 2000 only. If the wage equation includes education and country of origin, we get unconvincing results no matter how we specify the participation equation. In particular, the effect of years since migration is negative and the dummy for women gets a positive coefficient. We decided not to pursue this approach.

\section{Dip and catch-up: testing Duleep and Regets}

Duleep and Regets (1999) have used the human capital model to derive testable predictions for the "dip\&catch-up” model. In this model, immigrants start out at an economic disadvantage relative to natives but with increasing duration in the destination country they may catch up, with faster growth rates in wages and employment probability. Newly arrived immigrants have lower opportunity cost of human capital investment than natives, because of their wage dip upon arrival. They will also have higher returns to the extent that investments in destination country human capital increase the value of their home country human capital. Thus, they will invest more and have faster earnings growth (and thus will catch-up). Skill 
transferability between the home country and the destination country is an important variable, as this will affect the magnitude of the initial dip. The differences in wages and employment between source countries may be related to skill transferability, but we have not yet collected the additional data (eg on schooling systems) and we cannot yet test this theory. We may note however, that we have not found significant interaction effects between education and country of origin, between years since migration and education or between years since migration and source country in wage regressions. These issues need further research.

The core prediction of a negative relation between initial dip and the slope on years since migration is generally supported. In Figure 3, we plot the dummy coefficient for a source country against the interaction coefficient for that country with years since migration, from three regressions: the multinomial logits for employment and benefit status (Table 5) and the basic reference regression for wages in Table 8 (Model I). This means that we test the prediction by comparing immigrants from different countries rather than comparing immigrants with natives. Both for employment probability and for wages, the marginal effect of length of stay in The Netherlands is larger for immigrants from countries with a smaller country intercept. Note that this is not a necessary mechanical relationship. While a larger gap with natives indicates greater potential for growth, there is no need for this potential to be realised.

The prediction appears to hold also for the probability to receive social benefits. This might be explained indirectly, from build up of benefit entitlements through labour market experience: the better the employment history, the better the rights. It may also be explained, perhaps, from investment in social capital: getting to know your way around the institutions.

Figure 3. Country intercepts and country slopes on YSM

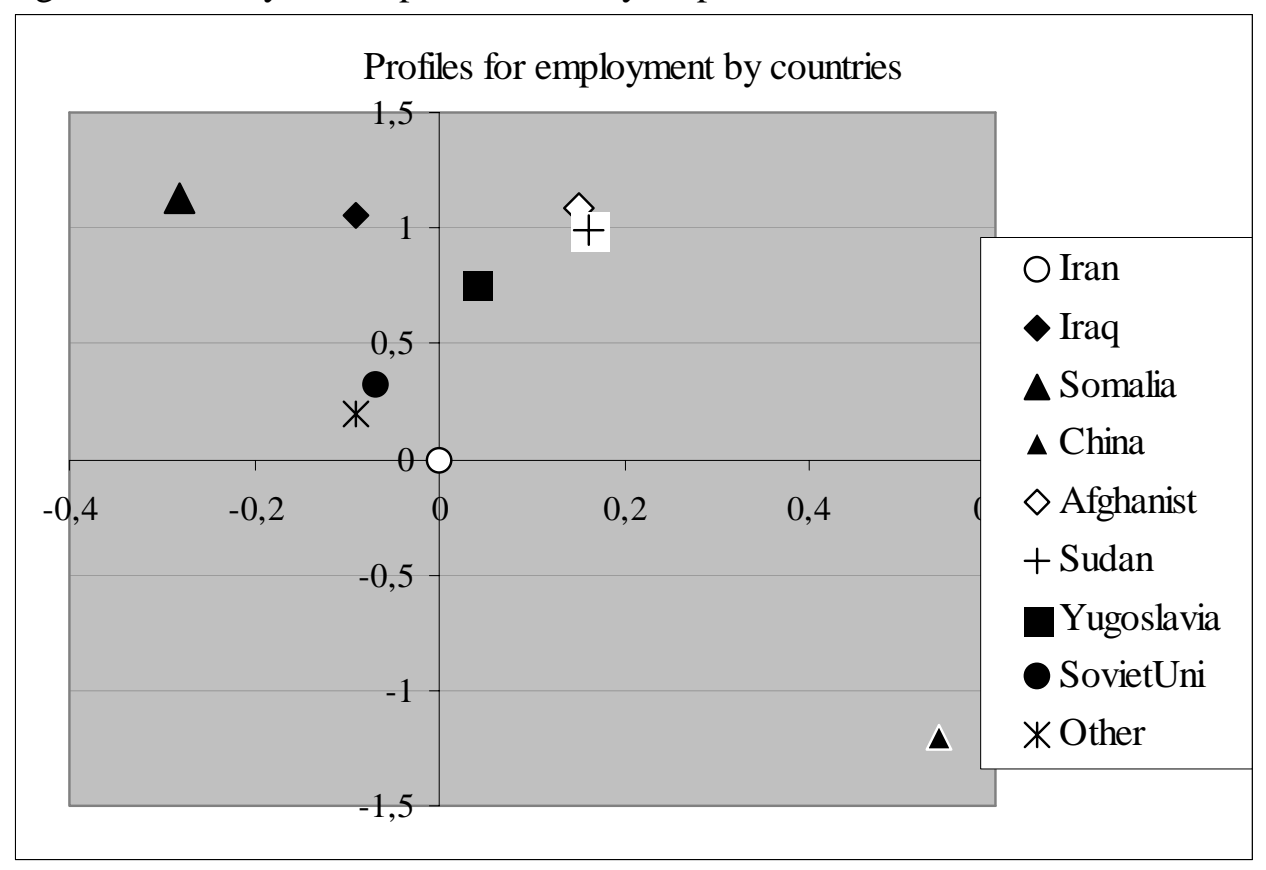



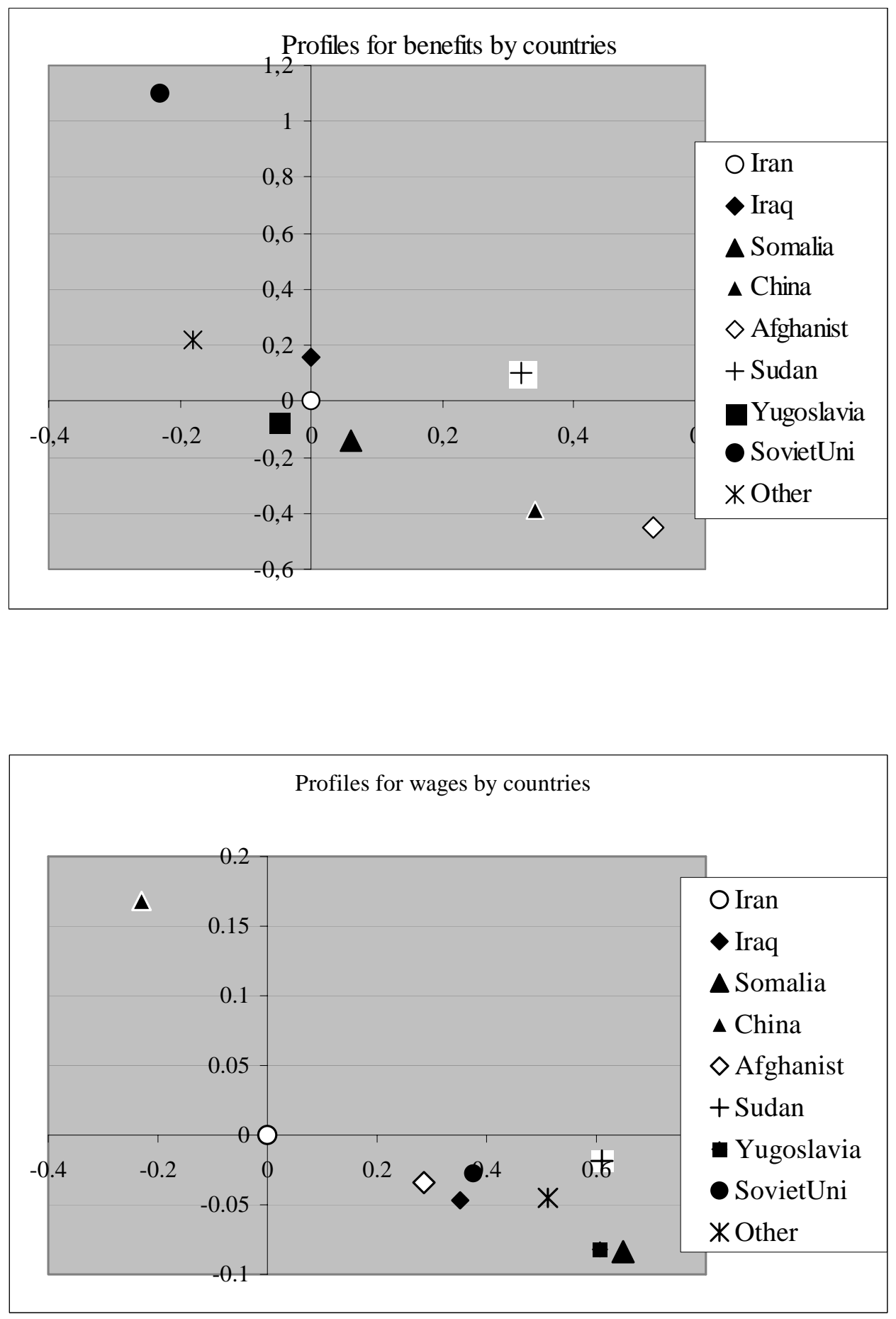

Note: the vertical axis measures the country specific intercept, the horizontal axis measure the coefficient on interaction between country of origin and years since migration. 


\section{Conclusion and possible explanations}

Our key finding is that for refugees higher educations acquired at home generally do not pay off during the first five years in the Dutch labour market. While remarkable, the outcome matches observations of persons active in refugee circles ${ }^{9}$. The result may be explained in several ways. One intervening variable may be language skills. It may very well be that for many of the occupations associated with higher educations understanding the Dutch language is vital, much more so than for lower levels of education. One can do cleaning work, construction work, much manufacturing work without good fluency in Dutch, as the results for Turkish and Moroccan immigrants in the Netherlands testify. One cannot be a physician without understanding Dutch properly. As we have no information on language proficiency we cannot test this, but such a hypothesis is clearly supported by Berman et al (2003) for Israel. It would be quite informative to observe jobs that immigrants hold before and after immigration, but such information is not available.

A related explanation may be certification. Several occupations that require high levels of education also require certification in the destination country. Even if one were fluent in Dutch, a qualified physician would not be allowed to take up his profession without obtaining new professional qualification in The Netherlands. Certification may have elements of discrimination and job protection, but may also have a basis in country specific required skills. ${ }^{10}$ Of course, even without certification there may be plain discrimination. Without further data, however, we cannot assess the empirical importance of these explanations.

Another explanation may be possible differences in health condition and true immigration motive. Refugees usually experience violence in their home country and may carry health affecting consequences of repression. Moreover, there is some doubt that every asylum seeker is a (political) refugee. Since legal immigration from developing countries is highly restrictive, some (economic) immigrants try to enter Netherlands via the asylum procedure. If political engagement is correlated with higher education levels, the population of economic immigrants who applied and secured a refugee position, is mostly from the lower end of the educational distribution. So, lower skilled refugees, if mainly economic immigrants, may be successful in the labour market while the value-added of higher skills of real refugees might be offset by health problems and long asylum procedures.

\footnotetext{
${ }^{9}$ We discussed our results with the immigration department of the Ministry of Home Affairs and with Vluchtelingenwerk Nederland, a foundation that supports newly arrived refugees.

${ }^{10}$ At the Mannheim presentation of this paper, someone remarked that his taxi driver to Stockholm airport had been a former Iraqi army general. Perhaps his skill might have been transferable, but his occupation certainly was not.
} 


\section{References}

Berman, E., K. Lang and E. Siniver (2003), Language-skill complementarity: returns to immigrant language acquisition, Labour Economics, 10 (3), 265-290

Cortes, K.(2004), Are refugees different from economic immigrants? Some empirical evidence on the heterogeneity of immigrant groups in the United States, Review of Economics and Statistics, 86(2), 465-480

Cramer, J.S. (2003), Logit models from economics and other fields, Cambridge: Cambridge University Press

Duleep, H. and M. Regets (1999), Immigrants and human capital investment, American Economic Review, 89 (2), Papers and Proceedings, 186-191

Friedberg, R.(2000), You can't take it with you? Immigrant assimilation and the portability of human capital, Journal of Labor Economics, 18 (2), 221-251

Kee, P (1993), The economic status of male immigrants in the Netherlands, Ph. D thesis, University of Amsterdam

Nekby, L. (2002), How long does it take to integrate? Employment convergence of immigrants and natives in Sweden, Stockholm: FIEF Working Paper Series 185

Wooldridge, J. (2002), Econometric Analysis of Cross Section and Panel Data, Cambridge: MIT Press 


\section{Appendix A The Immigrant Panel}

\section{The files}

All immigration by non-Dutch citizens is registered in the Central Register Foreigners (Centraal Register Vreemdelingen, CRV), using information from the Immigration Police (Vreemdelingen Politie) and the Immigration and Naturalisation Service (Immigratie- en Naturalisatie Dienst IND) ${ }^{11}$. At our request, CBS, the Dutch Central Bureau of Statistics, has linked the data to the Municipal Register of Population (Gemeentelijke Basisadministratie GBA). The GBA/CRV Register includes all nonDutch immigrants who legally entered The Netherlands during 1990-2001, except those who have returned before January 1, 1998, those who naturalised to Dutch citizenship and those who have died. As the Register takes stock every year on January 1, immigrants who left within the calendar year of arrival are also excluded. A problematic category is "administrative removal": immigrants removed from the files of one municipality without showing up in the files of another municipality or as emigrant. Administrative removals are included among return migration. However, there is no evidence that individuals have actually left The Netherlands. It is quite possible that many "administrative removals" remained in The Netherlands as illegal immigrant.

The GBA/CRV files have been linked to observations in the Regional Income Panel 1995-2000 (Regionaal Inkomens Onderzoek RIO), created by CBS. RIO is a panel of 2 million households, containing some 5 million individuals, about $30 \%$ of the population. The original GBA/CRV file covers about 600000 individuals, from which about a third can be retrieved in the RIO panel, thus generating a GBA/CRV/RIO file of some 200000 individuals. As immigrants in the GBA/CRV file have been linked to the RIO file in its base year 1995, the linked file covers about one third of the immigrants that have been registered in municipal population registers between 1990 and 1995 (however, the entry date in the register is not necessarily the entry date in The Netherlands, see below; registration in the municipal register is compulsory for every resident however). All immigrants registered after 1995 have been added to the data set; about one third of them could be linked to RIO. Naturalised immigrants are maintained in the RIO sample.

RIO gives panel information on disposable income and on socio-economic classification, both for individuals and for the household they belong to. The classification is based on the dominant income source during the year: employee, selfemployed, on disability, social assistance or unemployment benefit, other (mostly non-participating, without an individual income). Disposable income is defined as gross income minus taxes (on income and wealth) social security premiums and other transfers (such as alimony).

Information on level of education of immigrants is available in CRV if the immigration officer has bothered to register this (immigration officers consider it mostly irrelevant for their purpose); there is also registration of education for

\footnotetext{
${ }^{11}$ Note that we only consider non-Dutch immigrants.
} 
individuals who have contacted the government employment agency CIW to find a (new) job, obviously a very selective group.

Observations have been weighted, with weights reflecting gender by year of birth by age (older or younger than 18) by year of arrival (since 1990) by year of exit (deceased, migrated: 1998, 1999, 2000, still present).

\section{Refugees}

Asylum migrants (refugees) enter as applicants for asylum. Registered asylum migrants are immigrants who have been admitted, ie who have obtained a title of residence (refugees with a temporary status, A status, "AMA” (independents under 18), admission for humanitarian reason) and immigrants waiting for a decision on their asylum application. Admitted asylum migrants in principle are always registered in GBA. Registration for asylum applicants is variable. If they are registered in GBA at all, registration takes place several months after application. Since 1998, there are two special arrangements for asylum applicants. Under Zelfzorgarrangementen (Independent Housing) refugees find their own housing, with friends, relatives or otherwise. In this case they will always directly be registered in GBA. Under Central Housing, COA (Centrale Opvang voor Asielzoekers) takes care of housing. Asylum applicants in Central Housing are registered in GBA when they obtain asylum status or after spending one year in Central Housing (since June 2000, after spending 6 months). Most applicants were registered when they left Central Housing. This means that the group of asylum migrants contains an unknown share of asylum applicants, i.e. is an unknown mixture of admitted migrants and applicants for admission.

\section{Limitations of the dataset}

While the data set is unique in its perspective and coverage, as a follow-up on all immigrants arriving in The Netherlands, it is also imperative to point out its limitations: truncation, measurement errors, limited number of variables.

The CRV/GBA file basically includes all non-Dutch immigrants who legally entered The Netherlands during 1990 - 2001 and who have "survived" until at least January 1, 1998: they are only observed if at that date they are still living in the Netherlands as an immigrant. Thus, older cohorts of immigrants are truncated at departure (through death, emigration or naturalisation) before January 1, 1998. Moreover, information is collected on the stock of immigrants as per January 1. All immigrants leaving within the calendar year of arrival remain unobserved. This means that short durations are only observed if the interval of immigration contains January 1. In other words, precise information on short durations should be taken from durations covering January 1 . This is biased information if such spells of immigration differ from spells shorter than one year that do not include January 1.

One source of measurement error is particularly disturbing. Since "administrative removal" is counted as return migration in the GBA files, while it is not at all certain that these individuals have actually left the Netherlands, return migration will include an unknown number of illegal immigrants 
Information is limited to a small number of variables. GBA/CRV registers year of arrival, age, gender, country of origin, immigration motive, marital status, family composition, city of residence. RIO registers socio-economic category (employee, self-employed, disability, unemployment or welfare benefit, other), individual and household income. Category is measured from main income source during the year. Income itself is taken from fiscal records and has very high reliability. Education, a key variable, is poorly measured: in a standard classification scheme for those individuals who have visited the Employment Agency and for refugees if the Immigration Officer has bothered to fill out the entry at the application document. For the latter observations, ITS Nijmegen has coded the entries (the application document has an entry for all immigrants, but ITS only coded for refugees). We are grateful for their generous offer to add their coding to our dataset. 


\section{Appendix B Variable definitions}

Observations restricted to individuals aged 15-59

Arrival.year. (instroom): year of registration IND

Settlement.year (vestiging): year of registration GBA

Age: age at arrival in The Netherlands (ie at IND or GBA registration)

YSM: years since migration; years elapsed since registration GBA

Statuswait: settlement.year minus arrival.year, if positive, zero otherwise (year of GBA registration minus year of IND registration), hence time spent in refugee homes waiting for a decision on the application

Undocyears:: arrival.year minus settlement.year, if positive, zero otherwise (year of IND registration minus year of GBA registration); this applies when immigrants settled in the Netherlands without residential permission and without applying, undocumented immigrants could register at GBA without any sanction

Education: education as registered by IND and coded by ITS:
None
1-3 years basic
4-5 years basic
Basic
Extended basic
Secondary, general
Secondary, vocational
Some tertiary
Tertiary (higher vocational and university)
Missing

A status: permanent residential permission; date of granting status unknown

AMA: independent refugee not older than 18 at arrival

Naturalised: obtained Dutch citizenship in 2001

Returned: emigrated or administratively removed in 2001

Married: individual had marital status when arriving. 


\section{Appendix C. Additional Tables}

Table C1. Education by country of origin, three categories

\begin{tabular}{lrrrrr}
\hline & Primary & Secondary & Tertiary & Missing & Total $(\mathrm{N}=100)$ \\
\hline Iran & 7.27 & 39.17 & 10.98 & 42.58 & 674 \\
Iraq & 12.58 & 24.59 & 12.33 & 50.50 & 3,123 \\
Somalia & 42.45 & 23.91 & 2.52 & 31.12 & 874 \\
China & 53.85 & 19.58 & 0.23 & 26.34 & 429 \\
Afghanistan & 12.76 & 17.75 & 9.74 & 59.76 & 2,947 \\
Sudan & 15.15 & 27.61 & 18.52 & 38.72 & 594 \\
Yugoslavia & 15.09 & 43.55 & 2.67 & 38.68 & 1,272 \\
Soviet Union & 13.77 & 39.74 & 13.51 & 32.98 & 755 \\
Other countries & 31.03 & 28.11 & 4.34 & 36.52 & 2,768 \\
& & & & & \\
Total (\%) & 19.83 & 27.12 & 8.45 & 44.6 & 13,436 \\
Total (N) & 2,665 & 3,644 & 1,135 & 5,992 & \\
\hline
\end{tabular}


Table C2. Logit on education level registered (odds ratios)

\begin{tabular}{|c|c|c|}
\hline & Model_I & Model_II \\
\hline Age & $1.011 * * *$ & 1.002 \\
\hline Woman & $0.865 * * *$ & 1.040 \\
\hline arrival96 & $0.693 * * *$ & 0.753 \\
\hline arrival97 & $0.316 * * *$ & $0.683 * *$ \\
\hline arrival98 & $0.497 * * *$ & 1.200 \\
\hline arrival99 & $1.177^{* *}$ & 1.060 \\
\hline arrival00 & $3.615 * * *$ & $2.623 * *$ \\
\hline Undocyears & $0.846 * * *$ & 0.937 \\
\hline Statuswait & $0.250 * * *$ & 0.618 \\
\hline Iran (reference) & 1.000 & \\
\hline Iraq & 0.860 & 1.255 \\
\hline Somalia & $1.609 * * *$ & $2.169 * * *$ \\
\hline China & $2.284 * * *$ & $1.786 *$ \\
\hline Afghanistan & $0.540 * * *$ & 1.020 \\
\hline Sudan & 1.143 & 1.358 \\
\hline Yugoslavia & $0.798 * *$ & $1.532 *$ \\
\hline Soviet Union & $1.714 * * *$ & $1.606 *$ \\
\hline Other & $1.235 * *$ & $1.490 *$ \\
\hline Occupation: None & & $0.456 * * *$ \\
\hline Occupation: Unknown & & $0.002 * * *$ \\
\hline Occupation: Missing & & 1.182 \\
\hline A-status & & 0.839 \\
\hline AMA & & $1.658 * * *$ \\
\hline Emigrated & & 0.960 \\
\hline Naturalised & & 1.259 \\
\hline Married & & $1.191 * *$ \\
\hline Constant & $2.036 * * *$ & $13.324 * * *$ \\
\hline Chi2 & 1279.514 & 5256.350 \\
\hline Aic & 17445 & 5715 \\
\hline $\mathrm{Ll}$ & -8704.511 & -2831.545 \\
\hline $\mathrm{N}$ & 13720 & 13720 \\
\hline
\end{tabular}

